\title{
Toxic Effects of Organochlorine Pesticides: A Review
}

\author{
Zorawar Singh $^{1, ~ *, ~ J a s m i n d e r ~ K a u r ~}{ }^{1}$, Ravneet Kaur ${ }^{1}$, Swarndeep Singh Hundal ${ }^{2}$ \\ ${ }^{1}$ Department of Zoology, Khalsa College, Amritsar, Punjab, India \\ ${ }^{2}$ Department of Zoology, Punjab Agricultural University, Ludhiana, Punjab, India
}

Email address:

zorawarsinghs@rediffmail.com (Z. Singh), sshundal@pau.edu (S. S. Hundal)

${ }^{*}$ Corresponding author

\section{To cite this article:}

Zorawar Singh, Jasminder Kaur, Ravneet Kaur, Swarndeep Singh Hundal. Toxic Effects of Organochlorine Pesticides: A Review. American Journal of BioScience. Special Issue: Recent Trends in Experimental Toxicology. Vol. 4, No. 3-1, 2016, pp. 11-18. doi: 10.11648 j.ajbio.s.2016040301.13

Received: October 25, 2015; Accepted: November 23, 2016; Published: March 11, 2016

\begin{abstract}
This study is aimed at compiling the toxicological aspects of organochlorine compounds (OCCs) including pesticides among different animal models. Tests on animal species like Mean Probable Effect Concentration Quotient (PEC-Q) test, DNA repair assays and histopathological examinations have shown positive results for the toxicity of organochlorine pesticides. The results were observed on different animals including fishes, furseals, frogs, rats, bats and humans. In fishes, endosulfan is found to have acute toxicities. Similarly, organophosphorus, synthetic pyrethroids and microbial insecticides were also found to show their toxic effects. Some compounds such as lambda-cyhalothrin showed a very high toxicity on fish followed by fenvalerate, deltamethrin and cypermethrin. Exposure to OCCs can impart foe cell death by inducing Mitogen Activated Protein Kinase Pathway (MAPK) which is associated with cell growth differentiation and apoptosis. On studying the genotoxic effects of OCCs on germ cells of mouse, it was observed that a lethal mutation can occur just after one mating interval. Increase in the number of micronucleated cells has also been seen after OCC exposure. Neuro-behavioural studies on rats showed the presence of tremors caused by chlordecone and p,p'DDT. Tumorigenicity by organochlorine pesticides is seen to be an epigenetic mechanism in a DNA repair assay. Acute poisoning was seen in liver, kidney and testis of albino rat due to the toxic effect of dursban and DDT. Great declines in populations have been seen due to OCC toxicity in different animal species. Direct and indirect exposure to these compounds should be reduced so as to minimize the possible health hazards.
\end{abstract}

Keywords: Organochlorine Compounds, Organochlorine Pesticides, Polychlorinated Biphenyls, Toxicity, Endosulfan, Lindane, Dieldrin

\section{Introduction}

Organochlorines are the compounds which contain a minimum of one covalently bonded chlorine atom. Organochlorines exhibit a large variety of structures with much diverse chemical properties. Due to high atomic weight of chlorine, these compounds are found to be denser than water. These compounds can be prepared from chlorine, hydrogen chloride and from other chlorinating agents. Organochlorines could enter an organisms' body across the skin, from the lungs and could also be absorbed from the gut wall. Cyclodienes, hexachlorocyclohexane, endosulfan and lindane can easily pass through the skin, while the absorption is less in case of dicofol, toxaphene, DDT, mirex and methoxychlor [1]. It has been observed that absorption of organochlorines through skin and gut wall is greatly increased by fat and fat solvents. These compounds are volatile and their significant part is stored in fat tissue and is excreted through biliary and urinary pathways, while storable lipophilic compounds could be excreted from maternal milk. They affect central nervous system causing hyper-excitable state in brain, convulsions, tremor, hyper-reflexia and ataxia. Cyclodienes, lindane and mirex can cause more severe effects as compared to DDT and methoxychlor. DDT has been extensively tested for its possible toxic effects on different animal models [2-7]. Boyd and de Castro [8] researched on the relation of protein-deficient diet and DDT toxicity. Higher concentrations of organochlorines stimulate the tissues to produce more of hepatic microsomal drug metabolizing enzymes. Effects in humans can be seen on 
prolonged and intensive exposure. Organochlorines may also interact with endocrine receptors like of estrogen and androgens. Their poisoning may cause various symptoms including headache, nausea, dizziness, vomiting, tremor, lack of co-ordination and mental confusion. Organochlorine compounds (OCCs) can be detected in blood by gas-liquid chromatographic tests. Effective measures can be taken during early exposure stages so that harmful effects can be treated. Diazopam, Lorazepam and Cholestyramine resin are some of the treatment drugs used for organochlorine toxicity.

Organochlorine solvents are non-polar and are thus not miscible in water and are therefore used in degreasing and dry cleaning. The manufacturing mechanism of Teflon also includes the use of OCCs. DDT has been found to affect the peripheral nervous system and it was banned by the US government in 1972 [9]. These compounds are also used as insulating agents. But there is rapid metabolic disposition of methoxychlor, lindane, dienochlor, chlorobenzilate, endrin, toxaphene, perthane, endosulfan and dicofol, making them difficult to be detected in any fluid of the body of an animal. When the concentration of OCCs in body decreases below the threshold level, the organochlorine poisoning also reduces in the body. The ingestion of wheat treated with hexachlorobenzene results in dermal toxicity, also known as

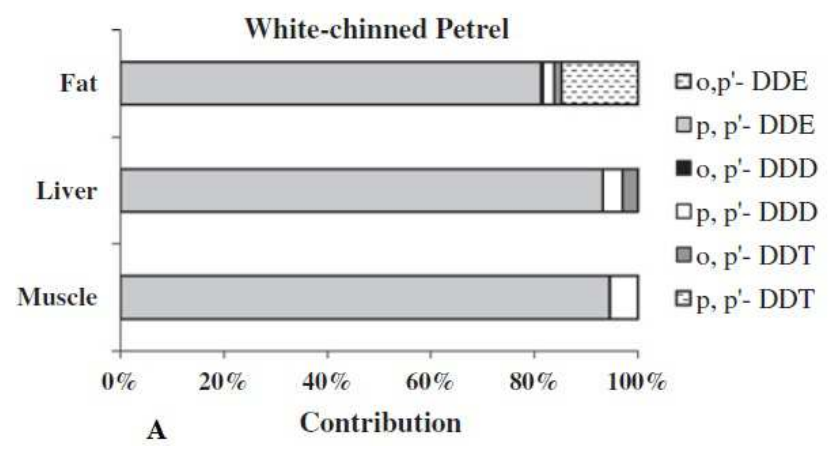

porphyria cutanea tarda [10-12]. This toxicity also results in skin hypersensitivity to sunlight and blisters on the skin. On subsequent poor healing, scarring and contracture formation occurs on skin [13]. Organochlorines may also have carcinogenic effects [14-20]. Respiratory depressions may also occur. The appearance of reports on concentrations of lindane found in body tissues has become very common. The absorption of lipophilic OCCs from the gastrointestinal tract has also been seen to greatly increase on consumption of animal and vegetable oils or fats. Thus the later compounds must be avoided especially by the person with symptoms of OCC toxicity. Mammals have high chances of increased organochlorine concentration as most of them occupy high trophic levels in food chains and food web, thus accumulating more of the toxic compounds in their body. High levels of these compounds are found in marine mammals of arctic region and even in breast milk of humans. The males of some marine mammalian species, especially those producing milk with high fat content, have been found to have far higher levels of organochlorine concentration as compared to the females of the same species. The lower concentration in females also reduces the chances of transfer of these compounds to their off-springs through lactation [21].

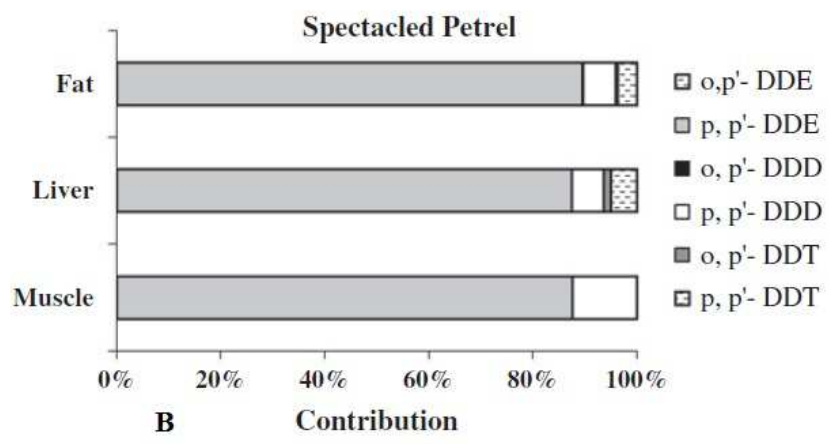

Figure 1. Relative mean contribution of DDTs found in different tissues of White-chinned Petrel and Spectacled Petrel (Reprinted from [22]).

DDT was much in use during the mid $20^{\text {th }}$ century for controlling the insect population, especially in the fields to grow disease free crops. But with time, it was noticed that DDT had started accumulating in different animals of the food chain [5]. Figure 1 (Reprinted from [22]) shows the relative mean contribution of DDTs found in different tissues of White-chinned Petrel and Spectacled Petrel. The accumulation of DDT in animals had caused various reproductive problems including the thinning of the eggshells of certain species of birds. This was resulting in the loss of off-springs of birds as these were not able to develop properly during their early embryonic growth, as the egg would hatch before complete development and the new born bird would die. This has endangered many bird species and is taking them to extinction. All in all, the benefits of organochlorine compounds being less, these are toxic and harmful to different animal species at different levels, and are therefore to be used with proper care.

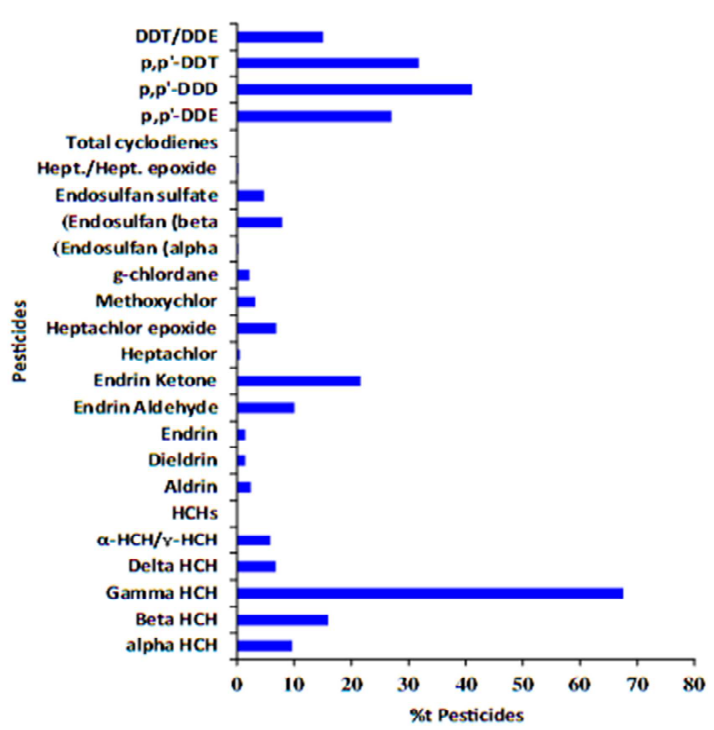

Figure 2. Pesticides pattern in shellfish tissues collected from the Mediterranean coast, Egypt (Reprinted from [23]). 
Herbicide metolachlor was not found to be much toxic to the earthworms, even at high concentrations. But when endosulfan and temephos were used along with metolachlor, activity of acetylcholinesterase was seen to be reduced. But application of melathion and primiphos-methyl along with metolachlor did not increase toxicity. Figure 2 (Reprinted from [23]) shows the pesticides pattern in shellfish tissues collected from the Mediterranean coast, Egypt.

\section{Toxicity Among Aquatic Organisms}

Organochlorine compounds have been found to have toxic effects on aquatic organisms [24-25]. To know the toxicity of organochlorine compounds (OCCs) and polychlorinated biphenyls (PCBs) in 845 stream sites across United States, 5 principal components have been identified that account for $77 \%$ of total variance of OCCs. These were 1 . Chlordane related compounds and Dieldrin 2. p,p'DDT and its derivatives 3. o,p'DDT and its degradates 4. Pesticide degradates of oxychlordane and hepatochlorepoxide and 5. Polychlorinated biphenyls.

To study the effects of endosulfan on the activity ethoxyresorufin-O-deethylase (EROD), glutathione-Stransferase (GST), superoxide dismutase (SOD), glutathione content, lipid peroxidation (LPO) and DNA strand break in gills and digestive glands of Ruditapes philippinarium (clams), they were exposed to $0.005,0.05$ and $0.5 \mu \mathrm{g} / \mathrm{L}$ endosulfan for 15 days [26]. The exposure resulted in the increase of EROD, GST, GSH, while SOD was seen to decrease. Use of termite controlling pesticides was found to be responsible for higher concentration of chlordane and dieldrin in urban cities. The Principal Component (PC) based mixture had one or more compounds associated with that PC. Unique mixtures are specifically combined with two or more compounds detected in a sample regardless of other compounds detected. The commonly obtained PC based mixtures were found in a variety of land use settings while complex mixtures occur in sample from urban sites. The potential toxicity of OCCs which is estimated by Mean Probable Effect Concentration Quotient (PEC-Q) was highest for complex mixtures. Thus PEC-Q in combination with PC based and unique mixture analysis can be used to relate potential aquatic toxicity of OCCs [27]. A study carried out for estimation of toxicity of organochlorine pesticides in the sediments at 20 sampling points, in Ebro River Basin, using detection limit (DL), revealed that DL concentrations of organochlorine pesticides were above the threshold level [28].

\section{Toxicity Among Fishes}

Various authors have tested the toxicity of different OCCs on different fish models [29-35]. Figure 3 (Reprinted from [36]) shows the comparison of concentrations of different organochlorine pesticide residues in wet and fat weight of Catfish. The acute toxicity of endosulfan in juvenile rainbow trout was evaluated in glass aquaria under static conditions. The first fish died after 4 hours after getting exposed to 26.3 $\mu \mathrm{g} / \mathrm{l}$ of endosulfan. Various other factors such as fish size also enhance rate of survival. Temperature and alkalinity also affect fish survival exposed to endosulfan. The exposed fishes showed severe focal necrosis in liver cells [37].

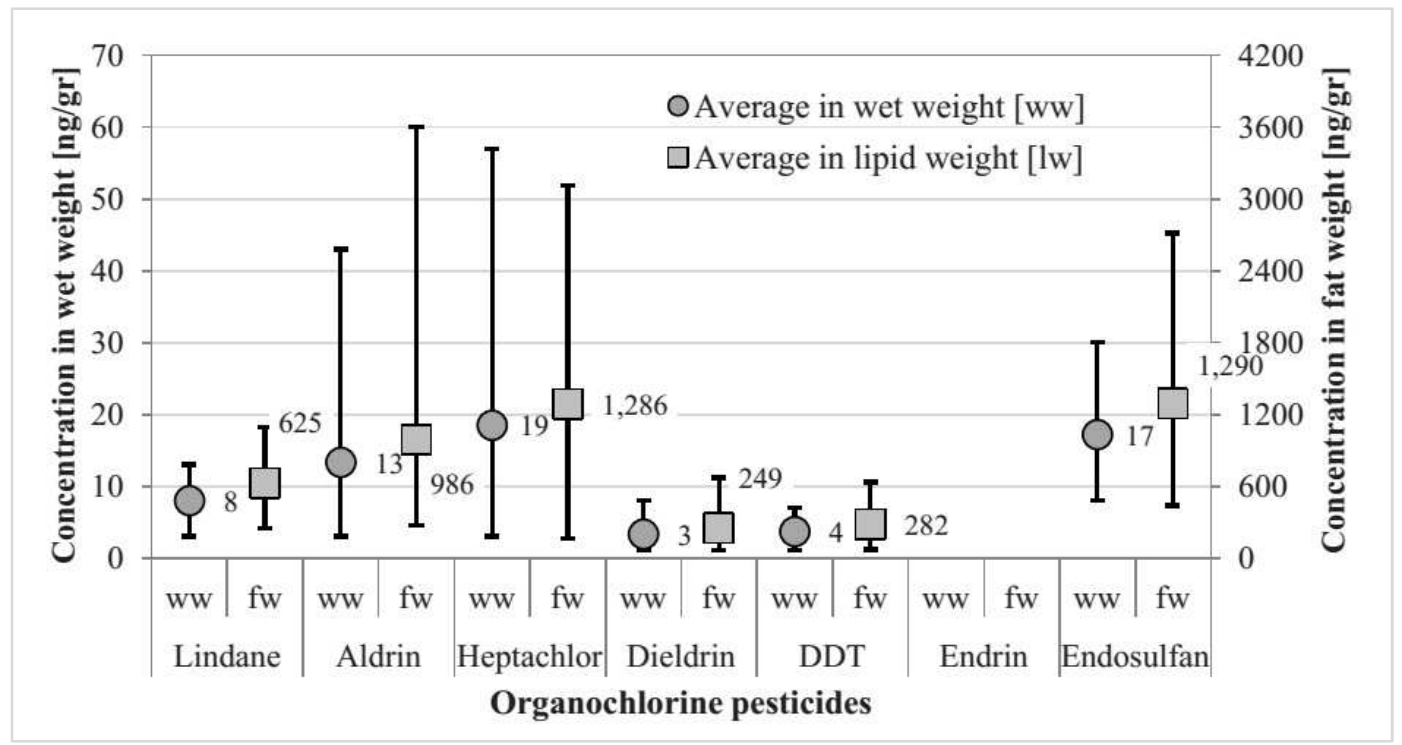

Figure 3. Concentration of organochlorine residue in catfish from Citarum Watershed (Reprinted from [36]).

It was found that mosquito fish Gambusia affinis suffered acutely by the toxic effect of OCC, organophosphorus, synthetic pyrethroids \& microbial insecticides. The synthetic pyrethroid, Lambda-cyhalothrin was most toxic to the fish $(\mathrm{LC50}=0.0022 \mathrm{ppm})$, followed by deltamethrin, cypermethrin and fenvalerate. Organochlorine insecticides,
DDT and gamma-HCH, were less toxic than the pyrethroids, and these were followed by organophosphorus insecticides, malathion, fenthion, monocrotophos and temephos [38].

The effects of endosulfan were also studied on juvenile Cyprinus carpio (common carp), for which fishes were exposed to endosulfan (95\% pure) diluted in $0.1 \%$ dimethyl 
sulphoxide (DSMO) in a semi-static system at sub-lethal concentration $(1 \mu \mathrm{g} / \mathrm{L})$ for 15 days. The activities of ethoxyresorufin-O-deethylase (EROD), total cytocrome P450 (CYP), CYP isoform from hepatic microsomal fraction; liver somatic index (LSI) and factor condition (K); oxidative stress enzyme system's activity like of catalase (CAT), superoxide dismutase (SOD), glutathione peroxidase, glutathione-Stransferase (GST), glutathione reductase (GR) and glucose-6phosphate dehydrogenase (G6PDH) were determined. Sublethal concentration of endosulfan showed an increase in oxidative stress in juvenile common carp [39]. An exposure of $0,0.25,1,2,3,4$ and $16 \mu \mathrm{g} / \mathrm{L}$ endosulfan in Cichlasoma dimerus for 96 hours was given to study the toxicity. Acetylcholine enzyme activity was found to remain normal in the brain. But a decrease in mean corpuscular haemoglobin and erythrocyte mean corpuscular volume were seen. Changes including hyperplasia of inter-lamellar epithelium and mucous cells, blood congestion in secondary lamellae, hypertrophy in gills, pycnotic nuclei, testicular damage and hydropic degeneration in liver were also seen [40].

\section{Toxicity Among Mammals}

The organochlorine compounds have largely been attributed to the declination of many species. One such species include Mexican free tailed bats (Tadarida brasiliensis) whose population declined from 8.7 million in 1936 to 20,000 in 1974 . Their habitats were largely contaminated \& disturbed. The potential genotoxic effect of OCCs on two different population of $T$. brasiliensis were studied and collected specimens showed pesticide residues in brain \& carcass tissues. Effect of organochlorine compounds on the chromosomal abberancy \& nuclear DNA content variation was also studied. A significant level of 1,1 Dichloro 2, 2 bis (p- bichlorophenyl) ethylene (DDE) contamination was observed in both the populations. Females were found to have lower levels of organochlorine compounds than males. A positive relationship between DDE concentration, carcass tissue and brain of bats was found. However a negative relationship was found between coefficient of variation in spleen DNA content \& brain DDE concentration, only for males [41]. Effects of OCC were also seen in Alaskan Furseal (Callorhinus ursinus). In Furseal, a better perspective of tissue congener distribution and toxic levels was found. The concentration of 145 Polychlorinated Biphenyl (PCBs) congeners and 12 organochlorine pesticides (OCPs) were measured with gas chromatography ion trap mass spectrometry. The concentration of Sigma-OCPs (ng/g lipid weight) were found to be 1180 in blubber, 985 in heart, 1007 in liver, 817 in kidney, 941 in muscle, 660 in reproductive tissue, 204 in brain and 322 in lung whereas the concentration of Sigma (145) PCBs (ng/g lipid weight) were found to be 823 in blubber, 777 in liver, 732 in heart, 646 in reproductive tissue, 638 in muscle, 587 in kidney, 128 in lung and 74.3 in brain tissue. This study lead to a view that PCB contamination has potentially affected the Northern furseal population [42].

\section{Toxicological Studies Among Rats}

The non-biodegradable nature of OCC such as Dieldrin and Lindane leads to their accumulation along the food chain thus making them ubiquitous in nature. Both have neurotoxic effects. When used in combination, these caused rapid increase in level of intracellular reactive oxygen species (ROS) and decreased mitochondrial membrane potential in rats whereas the effect gets suppressed, when the organisms are pre-treated with N-Acetyl cysteine. Thus both function in combination to induce dopaminergic neurotoxicity, oxidative stress and disfunctioning of mitochondria [43]. Parkinson disease is one such disorder which occurs due to continuous environmental exposure to the organochlorine pesticide. It is chronic and progressive disorder which leads to death of vital nerve cells of brain. Decreased level of dopamine leaves rats unable to control the movements.

According to a study, there were 27 most abundant contaminates found in blood of Canadian Arctic population studied through Northern Contaminant Mixture (NCM). From the first day of gestation until weaning spargue-dawly rat dams were dosed with polychlorinated biphenyls, organochlorine compounds and methyl mercury (Me-Hg) together with NCM or separately. Monitoring was done for offspring growth, TSH level, serum thyroxin, cerebellum and hippocampus protein expressions, brain taurine content and thyroid gland morphology. Observations for NCM and Me$\mathrm{Hg}$ treatment groups were impaired growth and increased mortality rate in pups. While PCB treatment caused perturbation of thyroid gland morphology and decreased level of circulating thyroxin [44]. OCCs also imparts foe cell death by inducing Mitogen activated protein kinase pathway (MAPK) which is associated with cell growth differentiation and apoptosis i.e. programmed cell death showing characteristic morphological and biochemical changes including fragmentation of nuclear DNA between the nucleosomes. MAPK also plays a key role in reproductive toxicity. Reactive oxygen species were also produced in this process [45].

The genotoxic end points for endosulfan were observed in mouse germ cells. A dominant lethal mutation was induced at higher doses of endosulfan in one mating interval. At significant dose level, sperm abnormalities were observed. Sperm count also decreased to $39 \%$. However, motility in sperms did not show any effect [46]. The neuro-behavioural toxicity of chlordecon, 1,1,1-trichloro-2,2-bi(p-chlorophenyl) ethane (DDT) and lindane was observed on rats. Tremor was observed by chlordecone and p,p'DDT exposure. Permethrin produced hyper-responsiveness similar to that of p,p'DDT. However, the hyper-responsiveness by permethrin and p,p'DDT was greatly reduced by phenytoin and increased when animal was dosed with chlordecone or lindane after pre-treatment with phenytoin. This suggested that the two groups of pesticides differ from each other in toxicity mechanisms [47].

DNA repair assay utilizing the hepatocytes from rats, mouse and hamster show tumorigenicity of OCP to be an 
epigenetic mechanism [48]. The effect of Dursban and DDT on the serum enzymes and histopathological examination of liver, kidney and testis of albino rat elicited acute poisoning. Dursban injected twice in a dose of the LD50 resulted in a significant increase in the serum GOT, GPT and alkaline phosphatase activity and decrease in cholinesterase activity. The pathological tests showed liver necrosis of mid zonal type, fatty change at the periphery and loss of radial arrangement of liver cells. It also resulted in swelling of convoluted tubules of kidneys and necrosis of seminiferous tubules of testis [49].

\section{Toxicity Among humans}

Different authors have proved DDT to be hazardous to humans by using different tests [50-55]. Shaw et al. [56] presented data on pesticide residues in milk from Indonesian women which demonstrated general exposure to p,p'-DDT and hexachlorobenzene (HCB). Similarly, different other studies [57-64] also demonstrated the presence of DDT in human milk. The use of titanium dioxide nanoparticles (nano- $\mathrm{TiO}_{2}$ ) for the degradation of dichlorodiphenyltrichloroethane ( $p, p^{\prime}-$ DDT) increases the risk of exposure to trace nano- $\mathrm{TiO}_{2}$ and p,p'-DDT mixtures. The interaction of p,p'-DDT and nano$\mathrm{TiO}_{2}$ at low concentrations may alter toxic response relative to nano- $\mathrm{TiO}_{2}$ or $\mathrm{p}, \mathrm{p}^{\prime}-\mathrm{DDT}$ alone. Addition of trace nano- $\mathrm{TiO}_{2}$ with p,p'-DDT synergistically enhanced genotoxicity via increasing oxidative stress, oxidative DNA adducts, DNA breaks, and chromosomal damage in human embryo L-02 hepatocytes.

By using human lymphocytes the possible genotoxic potential of DDE and HCB has been evaluated in-vitro. The result showed that DDE induced an increase in the number of micronucleated cells. DDE was tested in the range of 10-80 $\mathrm{mM}$, but the only concentration producing a significant genotoxic effect was $80 \mathrm{mM}$. On the other hand, HCB was unable to induce a significant increase in the $\mathrm{MN}$ frequency in the range of concentrations assayed, from 0.005 to $0.1 \mathrm{mM}$. The selected concentrations of DDE and HCB were chosen according to their toxicity in blood cell cultures; higher concentrations significantly reduced cell proliferation and produced a low frequency of binucleated cells [65]. The acute effect of organochlorine compounds was observed in agricultural pilots who were involved in hazardous task of spraying agricultural chemicals, most notably organophoshphate family of insecticides. During the instance of emergency landing made by professional agricultural pilots, there might occured some leakage of methomyl and endosulfan chemicals from aircrafts which gradually resulted in cholinergic symptoms. High dose of endosulfan lead to decreased sperm count upto $39 \%$ and damaging effect on spermatogonial cells as well as sperm morphology [66]. Health effects of PCB have also been described by a number of authors [67-73].

Cancer is known to be associated with the use of different OCCs in humans. DDT has also been found to be associated with the high occurrence of cancer among humans. Various authors have demonstrated the prevalence of different types of cancer with DTT exposures [55, 74-78]. Cytogenetic investigations have also been done for exposure to DDT in humans [79-80].

\section{Conclusion}

The data in this study presents the effect of organochlorine pesticides (OCPs) to be vast and devastating. OCPs, being non-biodegradable remain ubiquitous in environment and are the major pollutants. OCPs have been studied for their toxic effects on members of almost all phyla. They show multiple effects on the major physiological systems of the body including nervous, circulatory and reproductive system. The present study reveals that OCPs, at some critical growth periods, may generate severe health disturbances. Conclusively, the exposure to OCPs should be reduced so as to minimize the associated environmental and human health hazard.

\section{References}

[1] Echobichon D J, Klaasen C D, ed Cassarett, Doull's toxicology: Toxic effects of pesticides. The Basic Science of Poisons $5^{\text {th }}$ edition, New York, 1996; 649.

[2] Russell PF, Epstein S S: DDT toxicity. Science, 1972; 177: 387-388.

[3] Shaffi S: DDT toxicity, gluconeogenic enzymes and nonspecific phosphomonoesterases in three teleosts. Toxicol Lett, 1982; 13: 11-15.

[4] Shaffi SA, Dubey R P: DDT toxicity: variations in tissue nonspecific phosphomonoesterases and gluconeogenic enzymes in three teleosts. Acta Physiol Hung, 1989; 74: 57-62.

[5] Jaga K, Duvvi H: Risk reduction for DDT toxicity and carcinogenesis through dietary modification. $J$ R Soc Promot Health, 2001; 121: 107-113.

[6] Lotufo GR, Farrar JD, Duke BM, Bridges T S: DDT toxicity and critical body residue in the amphipod Leptocheirus plumulosus in exposures to spiked sediment. Arch Environ Contam Toxicol, 2001; 41: 142-150.

[7] De P C, Trimble A J, Maul J D, Lydy M J: Ecological bioavailability of permethrin and p,p'-DDT: toxicity depends on type of organic matter resource. Chemosphere, 2014; 96: 67-73.

[8] Boyd E M, de Castro: Protein-deficient diet and DDT toxicity. Bull World Health Organ, 1968; 38: 141-150.

[9] EPA, Environmental protection Agency 1975 http://www2.epa.gov/aboutepa/ddt-ban-takes-effect. Cited on Nov. $2^{\text {nd }}, 2015$.

[10] Khayat R, Dupuy A, Panse I, Bagot M, Cordoliani F: Sclerodermatous changes in porphyria cutanea tarda: six cases. Ann Dermatol Venereol, 2013; 140: 589-597.

[11] Wallaeys E, Thierling U, Lang E, Neumann NJ, Frank J (Toxicol Lett 2292014). [Porphyria cutanea tarda with sclerodermatous changes and hemochromatosis]. Hautarzt 65: 272-27425. 
[12] Andersen J, Gjengedal E, Sandberg S, Raheim M: A skin disease or blood disease or something in between, an exploratory focus group study of patients experiences with porphyria cutanea tarda. Br J Dermatol, 2015; 172: 223-229.

[13] Booth N H, Mc Dowells J R: Toxicity of hexachlorobenzene and associated residues in edible animal tissue. JAM Vet Med Association, 1975; 166(6): 591-595.

[14] Song L, Zhao J, Jin X, Li Z, Newton IP, Liu W, Xiao H, Zhao M: The organochlorine p,p'-dichlorodiphenyltrichloroethane induces colorectal cancer growth through Wnt/beta-catenin signalling. Toxicol Lett, 2014; 229: 284-291.

[15] Arrebola J P, Belhassen H, Artacho-Cordon F, Ghali R, Ghorbel H, Boussen H, Perez-Carrascosa F M, Exposito J, Hedhili A, Olea: Risk of female breast cancer and serum concentrations of organochlorine pesticides and polychlorinated biphenyls: a case-control study in Tunisia. Sci Total Environ, 2015; 520: 106-113.

[16] Kim SA, Kim KS, Lee YM, Jacobs DR, Lee DH: Associations of organochlorine pesticides and polychlorinated biphenyls with total, cardiovascular, and cancer mortality in elders with differing fat mass. Environ Res, 2015; 138: 1-7.

[17] Koutros S, Langseth H, Grimsrud TK, Barr DB, Vermeulen R, Portengen L, Wacholder S, Beane Freeman LE, Blair A, Hayes RB, Rothmann N, Engel L S : Prediagnostic Serum Organochlorine Concentrations and Metastatic Prostate Cancer: A Nested Case-Control Study in the Norwegian Janus Serum Bank Cohort. Environ Health Perspect, 2015; 123(9): 867-72.

[18] Lewis-Mikhael AM, Olmedo-Requena R, Martinez-Ruiz V, Bueno-Cavanillas A, Jimenez-Moleon J J: Organochlorine pesticides and prostate cancer, Is there an association? A meta-analysis of epidemiological evidence. Cancer Causes Control, 2015; 26(10): 1375-92.

[19] Parada H, Jr. Wolff MS, Engel LS, White AJ, Eng SM, Cleveland RJ, Khankari NK, Teitelbaum SL, Neugut AI, Gammon M D: Organochlorine insecticides DDT and chlordane in relation to survival following breast cancer. Int $J$ Cancer, 2015; doi: 10.1002/ijc.29806. [Epub ahead of print]

[20] Rivero J, Luzardo OP, Henriquez-Hernandez LA, Machin RP, Pestano J, Zumbado M, Boada LD, Camacho M, Valeron P F: In vitro evaluation of oestrogenic/androgenic activity of the serum organochlorine pesticide mixtures previously described in a breast cancer case-control study. Sci Total Environ, 2015; 537: 197-202.

[21] Dierauf, Gulland: Marine Mammal Medicine, 2001; CRC Press.

[22] Colabuono FI, Taniguchi S, Montone RC: Organochlorine contaminants in albatrosses and petrels during migration in South Atlantic Ocean. Chemosphere, 2012; 86(7): 701-8.

[23] Salem A, Sikaily A, Nemr A: Organochlorines and their risk in marine shellfish collected from the Mediterranean coast, Egypt. Egyptian Journal of Aquatic Research, 2014, 40: 93101.

[24] Zhou HY, Cheung RY, Wong MH: Residues of organochlorines in sediments and tilapia collected from inland water systems of Hong Kong. Arch Environ Contam Toxicol, 1999; 36: 424-431.
[25] Wang Y, Qiu YL, Fei Y, Li L, Zhu ZL, Zhao JF, Yao EQ, Yao $\mathrm{Y}$ X: Measurement and preliminary human health risk assessment of representative organochlorines in farmed Mandarin fish. Huan Jing Ke Xue, 2011; 32: 2385-2390.

[26] Tao Y, Pan L, Zhang H, Tian S: Assessment of the toxicity of organochlorine pesticide endosulfan in clams (Ruditapes philippinarum). Ecotoxicol Environ Saf, 2013; 93: 22-30.

[27] Phillips PJ, Nowell LH, Gilliom R J, Nakagaki N, Murray KR, Van Alstyne C: Composition, distribution and potential toxicity of organochlorine mixtures in bed sediments of streams. Sci Total Environ, 2010; 408: 594-606.

[28] Veses O, Mosteo R, Ormad M P, Ovelleiro J L: Potential toxicity of Polycyclic Aromatic Hydrocarbons and organochlorine pesticides in sediments from the Erbo River in Spain. Bull Environ Contam Toxicol, 2012; 88: 644-650.

[29] Deribe E, Rosseland B O, Borgstrom R, Salbu B, Gebremariam Z, Dadebo E, Skipperud L, Eklo O M: Organochlorine pesticides and polychlorinated biphenyls in fish from Lake Awassa in the Ethiopian Rift Valley: human health risks. Bull Environ Contam Toxicol, 2014; 93: 238-244.

[30] Yohannes YB, Ikenaka Y, Saengtienchai A, Watanabe KP, Nakayama S M, Ishizuka M: Concentrations and human health risk assessment of organochlorine pesticides in edible fish species from a Rift Valley lake-Lake Ziway, Ethiopia. Ecotoxicol Environ Saf, 2014; 106: 95-101.

[31] Yohannes YB, Ikenaka Y, Nakayama S M, Ishizuka M: Organochlorine pesticides in bird species and their prey (fish) from the Ethiopian Rift Valley region, Ethiopia. Environ Pollut, 2014; 192: 121-128.

[32] Zhang Y, Lin N, Su S, Shen G, Chen Y, Yang C, Li W, Shen H, Huang Y, Chen H, Wang X, Liu W, Tao S: Freeze drying reduces the extractability of organochlorine pesticides in fish muscle tissue by microwave-assisted method. Environ Pollut, 2014; 191: 250-252.

[33] Byrne S, Miller P, Waghiyi V, Buck C L, von Hippel F A, Carpenter D O: Persistent Organochlorine Pesticide Exposure Related to a Formerly Used Defense Site on St. Lawrence Island, Alaska: Data from Sentinel Fish and Human Sera. $J$ Toxicol Environ Health A, 2015; 78: 976-992.

[34] Cui L, Ge J, Zhu Y, Yang Y, Wang J: Concentrations, bioaccumulation, and human health risk assessment of organochlorine pesticides and heavy metals in edible fish from Wuhan, China. Environ Sci Pollut Res Int, 2015 [Epub ahead of print].

[35] Wang J, Liang W, Henkelmann B, Pfister G, Schramm KW: Organochlorine pesticides accumulated by SPMD-based virtual organisms and feral fish in Three Gorges Reservoir, China. Environ Pollut, 2015; 202: 160-167.

[36] Rahmawati S, Margana G, Yoneda M, Oginawati K: Organochlorine pesticide residue in Catfish (Clarias $s p$.) collected from local fish cultivation at Citarum watershed, West Java Province, Indonesia. Proced Env Sci, 2013; 17: 3-10.

[37] Capkin E, Altinok I, Karahan S: Water quality and fish size affect toxicity of endosulfan, an organochlorine pesticide, to rainbow trout. Chemosphere, 2006; 64: 1793-1800.

[38] Mittal P K, Adak T, Sharma V P: Acute toxicity of certain organochlorine, organophosphorus, synthetic pyrethhroid and microbial insecticides to the mosquito fish (Gambusia affinis). Indian J malarial, 1991; 28: 167-170. 
[39] Salvo LM, Bainy AC, Ventura EC, Marques MR, Silva J R, Klemz C, Silva de Assis H C: Assessment of the sub lethal of organochlorine pesticide endosulfan in juvenile common carp (Cyprinus carpio). J Environ Sci Health Tox Hazard Subst Environ Eng, 2012; 47: 1652-1658.

[40] Da Cuna R H, Rey V G, Piol M N, Guerrero N V, Maggese M C, Lo Nostro F L: Assessment of the acute toxicity of the organochlorine pesticide endosulfan in Cichlasoma dimerus (Teleostei, perciformes). Ecotoxical Environ Saf, 2011; 74: $1065-1073$.

[41] Thies M L, Thies K, McBee K: Organochlorine pesticide accumulation and genotoxicity in Mexican free tailed bats from Oklarhoma and New Mexico. Arch Environ Contam Toxicol, 1996; 30: 178-187.

[42] Wang D, Shelver WL, Atkinson S, Mellish J A, Li Q X: Tissue distribution of polychlorinated biphenyls and organochlorine pesticides and potential toxicity to Alaskan northern fur seals assessed using PCBs congener specific mode of action schemes. Arch Environ Contam Toxicol, 2010; 58: 478-488.

[43] Sharma H, Zhang P, Barber D S, Liu B: Organochlorine pesticides dieldrin and lindane induce cooperative toxicity in dopaminergic neurons. Role of Oxidative stress, Neurotoxicology, 2010; 31: 215-222.

[44] Pelletier G, Masson S, Wade MJ, Nakai J, Alwis R, Mohottalage S, Kumaranthasan P, Black P, Bowers W J, Chu I, Vincent R: Contribution of methylmercury, polychlorinated biphenyls and organochlorine pesticides to the toxicityn of a contaminant mixture based on Canadian arctic population blood profiles. Toxicol left, 2009; 184: 176-185.

[45] Yu H, Yang K: Mechanism of mitogen- activated protein kinase pathway in male reproductive toxicity induced organochlorine pesticides. Wei Sheng Yan Jiu, 2007; 36: 7568,762 .

[46] Pandey N, Gundevia F, Prem A S, Ray P K: Studies on the genotoxicity of endosulfan, an organochlorine insecticide, in mammalian germ cells. Mutat Res, 1990; 242: 1-7.

[47] Tilson HA, Hong JS, Mactutus C F: Effect of 5, 5diphenylhydantoin (phenytoin) on neurobehavioral toxicity of organochlorine insecticides and permethrin. J Pharmacol Exp Ther, 1985; 233: 285-289.

[48] Maslansky C J, Williams G M: Evidence for an epigenetic mode of action in organochlorine pesticides hepatocarcinogenicity, a lack of genotoxicity in rat, mouse and hamster hepatocytes. $J$ Toxicol Environ Health, 1981; 8: 121130 .

[49] Mikhail TH, Aggour N, Awadallah R, Boulos MN, Eldessoukey E, Karima A L: Acute toxicity of organophosphorus and organochlorine insecticides in laboratory animals. Z Ernahrungswiss, 1979; 18: 258-268.

[50] Cardenas-Gonzalez M, Gaspar-Ramirez O, Perez-Vazquez FJ, Alegria-Torres JA, Gonzalez- Amaro R, Perez-Maldonado IN: p,p'-DDE, a DDT metabolite, induces proinflammatory molecules in human peripheral blood mononuclear cells "in vitro". Exp Toxicol Pathol, 2013; 65: 661-665.

[51] Byard JL, Paulsen SC, Tjeerdema RS, Chiavelli D: DDT, chlordane, toxaphene and PCB residues in Newport Bay and Watershed: assessment of hazard to wildlife and human health. Rev Environ Contam Toxicol, 235: 49-168.
[52] Everett CJ, Thompson OM: Association of DDT and heptachlor epoxide in human blood with diabetic nephropathy. Rev Environ Health, 2015; 30: 93-97.

[53] Pavlikova N, Smetana P, Halada P, Kovar J: Effect of prolonged exposure to sublethal concentrations of DDT and DDE on protein expression in human pancreatic beta cells. Environ Res, 2015; 142: 257-263.

[54] Strong AL, Shi Z, Strong MJ, Miller DF, Rusch DB, Buechlein AM, Flemington EK, McLachlan JA, Nephew KP, Burow ME, Bunnell BA: Effects of the endocrine-disrupting chemical DDT on self-renewal and differentiation of human mesenchymal stem cells. Environ Health Perspect, 2015; 123: $42-48$

[55] Wong LI, Labrecque MP, Ibuki N, Cox ME, Elliott JE, Beischlag TV: p,p'-Dichlorodiphenyltrichloroethane ( $p, p^{\prime}$ DDT) and p,p'-dichlorodiphenyldichloroethylene (p,p'-DDE) repress prostate specific antigen levels in human prostate cancer cell lines. Chem Biol Interact, 2015; 230: 40-49.

[56] Shaw I, Burke E, Suharyanto F, Sihombing G: Residues of p,p'DDT and hexachlorobenzene in human milk from Indonesian women. Environ Sci Pollut Res Int. 2000; 7(2): 75-7.

[57] Smith D: Worldwide trends in DDT levels in human breast milk. Int J Epidemiol, 1999; 28: 179-188.

[58] Shaw I, Burke E, Suharyanto F, Sihombing G: Residues of p,p'-DDT and hexachlorobenzene in human milk from Indonesian women. Environ Sci Pollut Res Int, 2000; 7: 75-77.

[59] Dorner G, Plagemann A: DDT in human milk and mental capacities in children at school age: an additional view on PISA 2000. Neuro Endocrinol Lett, 2002; 23: 427-431.

[60] Wong MH, Leung AO, Chan JK, Choi MP: A review on the usage of POP pesticides in China, with emphasis on DDT loadings in human milk. Chemosphere, 2005; 60: 740-752.

[61] Zimmermann E, Pedersen JO, Saraubon K, Tjell JC, Prapamontol T: DDT in human milk from Chiang Mai mothers: a public health perspective on infants' exposure. Bull Environ Contam Toxicol, 2005; 74: 407-414.

[62] Bouwman H, Sereda B, Meinhardt HM: Simultaneous presence of DDT and pyrethroid residues in human breast milk from a malaria endemic area in South Africa. Environ Pollut, 2006; 144: 902-917.

[63] Hui LL, Hedley AJ, Kypke K, Cowling BJ, Nelson EA, Wong TW, van Leeuwen FX, Malisch R: DDT levels in human milk in Hong Kong, 2001-02. Chemosphere, 2008; 73: 50-55.

[64] Okonkwo JO, Mutshatshi TN, Botha B, Agyei N: DDT, DDE and DDD in human milk from South Africa. Bull Environ Contam Toxicol, 2008; 81: 348-354.

[65] Ennaceur S, Ridha D, Marcos R: Genotoxicity of the organochlorine pesticides 1, 1-dichloro -2, 2-bis (p-chloro phenyl) ethylene (DDE) and hexachlorobenzene (HCB) in cultured human lymphocytes. Chemosphere, 2008; 71: 13351339.

[66] Cable G G, Doherty S: Acute carbamate and organochlorine toxicity causing convulsions in an agricultural pilot. Avait Space Environ Med, 1999; 70: 68-72. 
[67] Di MA, Camoni I, Dommarco R, Santilio A, Ausili A, Rizzica M, Gigli B, Calzolari C: Evaluation of p,p'-DDE, p,p'-DDT and polychlorobiphenyls (PCBs) levels in samples of human milk from Rome, Florence and the surrounding areas. Ann Ist Super Sanita, 1990; 26: 155-160.

[68] Galetin-Smith R, Pavkov S, Roncevic N: DDT and PCBs in human milk: implication for breast feeding infants. Bull Environ Contam Toxicol, 1990; 45: 811-818.

[69] Mohammed A, Eklund A, Ostlund-Lindqvist AM, Slanina P: Distribution of toxaphene, DDT, and PCB among lipoprotein fractions in rat and human plasma. Arch Toxicol, 1990; 64: 567-571.

[70] Horn M, Heinzow B, Dolk G: Burden of DDT, HCH, HCB and PCB in human milk in the former German Democratic Republic. Research and toxicologic evaluation. Zentralbl Hyg Umweltmed, 1994; 196: 95-103.

[71] Chikuni O, Nhachi CF, Nyazema NZ, Polder A, Nafstad I, Skaare JU: Assessment of environmental pollution by PCBs, DDT and its metabolites using human milk of mothers in Zimbabwe. Sci Total Environ, 1997; 199: 183-190.

[72] Longnecker MP, Rogan WJ, Lucier G: The human health effects of DDT (dichlorodiphenyltrichloroethane) and PCBS (polychlorinated biphenyls) and an overview of organochlorines in public health. Annu Rev Public Health, 1997; 18: 211-244.

[73] Byard JL, Paulsen SC, Tjeerdema RS, Chiavelli D: DDT, chlordane, toxaphene and PCB residues in Newport Bay and Watershed: assessment of hazard to wildlife and human health. Rev Environ Contam Toxicol, 2015; 235: 49-168.
[74] Enan E, Matsumura F: Activation of c-Neu tyrosine kinase by o,p'-DDT and beta-HCH in cell-free and intact cell preparations from MCF-7 human breast cancer cells. $J$ Biochem Mol Toxicol, 1998; 12: 83-92.

[75] Wang XQ, Gao PY, Lin YZ, Chen CM: Studies on hexachlorocyclohexane and DDT contents in human cerumen and their relationships to cancer mortality. Biomed Environ Sci, 1988; 1: 138-151.

[76] Diel P, Olff S, Schmidt S, Michna H: Effects of the environmental estrogens bisphenol A, o,p'-DDT, p-tertoctylphenol and coumestrol on apoptosis induction, cell proliferation and the expression of estrogen sensitive molecular parameters in the human breast cancer cell line MCF-7. J Steroid Biochem Mol Biol, 2002; 80: 61-70.

[77] Han EH, Kim HG, Hwang YP, Choi JH, Im JH, Park B, Yang $\mathrm{JH}$, Jeong TC, Jeong HG: The role of cyclooxygenase-2dependent signaling via cyclic AMP response element activation on aromatase up-regulation by o,p'-DDT in human breast cancer cells. Toxicol Lett, 2010; 198: 331-341.

[78] Ndebele K, Graham B, Tchounwou PB: Estrogenic activity of coumestrol, DDT, and TCDD in human cervical cancer cells. Int J Environ Res Public Health, 2010; 7: 2045-2056.

[79] Lessa JM, Becak W, Nazareth RM, Pereira CA, Ungaro MT: Cytogenetic study of DDT on human lymphocytes in vitro. Mutat Res, 1976; 40: 131-138.

[80] Geric M, Ceraj-Ceric N, Gajski G, Vasilic Z, Capuder Z, Garaj-Vrhovac V: Cytogenetic status of human lymphocytes after exposure to low concentrations of p,p'-DDT, and its metabolites (p,p'-DDE, and p,p'-DDD) in vitro. Chemosphere, 2012; 87: 1288-1294. 